\title{
O perfil institucional do Estado português nos séculos XV-XVI
}

João Cerineu Leite de Carvalho ${ }^{1}$

Falar em história medieval no Brasil, muitas vezes, soa como algo despropositado, sem objetivo ou validade suficientes para que algum destaque maior lhe seja atribuído. Olhando para o lançamento do embrião que viria a se tornar o Brasil - desde as tímidas e incertas incursões iniciais portuguesas em continente americano -, nos parece mais acertado incluir a grande maioria dos estudos que envolvem a história brasileira no contexto moderno das grandes navegações que se desenvolvia a partir da Europa. Contudo, desconectar o estudo da colonização brasileira e do Estado Português se torna impossível, uma vez que "brasileiros” só virão a existir muito tempo depois das primeiras décadas da colônia lusa nas Américas.

Compreender, então, o Estado moderno português e sua estrutura, para chegarmos à raiz do que fora implantado em território americano é o que devemos fazer - diríamos, fazendo uma associação lógica. Nada de Idade Média para nós, já que no Brasil não houve uma Idade Média. Seria um erro trazer essa classificação européia para a América, assim como levá-la para África ou Ásia.

O questionamento que fica, porém, é: de que maneira se define o Estado português quatrocentista e quinhentista (o das Navegações e Descobrimentos)? Qual é o perfil dessa instituição política, que leva a fama de primeira nação européia onde o poder régio teria se centralizado sobre um território claramente definido praticamente desde a baixa Idade Média? O que buscaremos apontar aqui nesse ensaio é que se, por um lado, Portugal unia "para o melhor e para o pior, os ramos enormemente diversificados da família humana” ${ }^{2}$ - se configurando em um reino de grande peso para a Europa que adentrava a modernidade -, também se via envolvido em um combate interno contra poderosas forças centrífugas, que tinham suas origens nos particularismos característicos da Idade Média.

A partir da perspectiva da história das instituições jurídicas, buscamos definir o perfil institucional do Estado português em um momento crítico de sua história - por assumir uma posição de grande destaque no cenário europeu e procurar uma reestruturação ao lidar com profundas mudanças trazidas pela expansão marítima - no período entre o princípio do século XV e o primeiro quarto do século XVI.

Partindo do pressuposto que a história do direito atualmente tem como objetivo produzir conhecimento através da reconstituição de sistemas ou fatos jurídicos que se deram no passado, e que o direito se constitui em um mecanismo de disciplina social, afirmamos ser possível enxergar a estrutura jurídica do Portugal dos séculos XV e XVI como uma estrutura histórica em si.

Segundo afirmação de Marcello Caetano - falando especificamente sobre Portugal - “o direito é um fato cultural: há direito português na medida em que se formou uma comunidade de pessoas geradora de uma cultura própria.” ${ }^{3} \mathrm{O}$ mesmo autor nos fala que, para um historiador do direito, é indispensável o cuidado em não desligar a evolução do direito de um povo que esteja sendo estudado da evolução história do mesmo, "partindo do princípio de que o direito não é um produto arbitrário de vontades, mas uma resposta às necessidades sentidas pela comunidade tal como são manifestadas pelos interessados e interpretadas pelos governantes.” " Da mesma maneira, se mostra indispensável correlacionar os aspectos jurídicos de uma dada época com as mais diversas circunstâncias sociais: política, economia, correntes ideológicas, etc.

O direito se mostra como uma criação que visa, em primeira instância, legitimar a obediência daqueles que, submetidos a determinado conjunto de normas, têm sua liberdade limitada. É um forte mecanismo de imposição de uma disciplina social, ou de dominação de uma sociedade.

Devemos analisar a construção do direito como de qualquer outra estrutura social e não de características intrínsecas de normas supostamente universais e atemporais. Em outras palavras, que a regulamentação jurídica é fruto de uma formação advinda do contexto em que é criada. Tentamos demonstrar que o modelo de história política oitoscentista - no qual o direito seria construído de cima para baixo - dá lugar ao pensamento que vê a normatização como uma explicitação por parte dos juristas, em especial na Idade Média e Moderna, da prática cotidiana dos povos.

\footnotetext{
${ }^{1}$ Bacharel em História pela UNIRIO.

2 BOXER, Charles R. O Império Marítimo Português: 1415-1825. São Paulo - SP: Companhia das Letras, 2002. p. 16

${ }^{3}$ CAETANO, Marcello. História do direito português (séc.s XII-XVI). seguida de Subsídios para a história das fontes do direito em Portugal no séc. XVI. Editorial Verbo: Lisboa, 2000. p. 25.

${ }^{4}$ Ibid. p. 27.
} 
Buscamos, com isso, fugir da idéia de estadualismo, na qual o único poder efetivo seria do Estado, nos voltando para a concepção de que a normatização social é efetuada em múltiplos níveis. Justamente por essa pluralidade existir é que o Estado criaria mecanismos capazes de rivalizar e subjugar outras forças, ampliando o controle sobre a vida das pessoas.

O modelo de organização jurídica de que trataremos - que começa a ser praticado na Europa Ocidental na Baixa Idade Média - descende em parte do resgate promovido, neste mesmo período, do direito romano (a partir das codificações Justinianas).

O direito romano foi renegado à escuridão na Idade Média, período em que os costumes locais, mesclados aos direitos dos novos habitantes europeus - os povos de origem germânica -, tiveram papel muito presente no cotidiano das populações. A influência de Roma, contudo, permaneceu presente no Ocidente. São conservadas características romanas na organização administrativa e religiosa por séculos, "nas regiões profundamente romanizadas do Sul da Gália e sobretudo das penínsulas Ibérica e Itálica, onde a corrente germânica chegou fortemente enfraquecida, dominou um direito romano" 5

$\mathrm{O}$ resgate do direito romano pode ser atribuído em muito à Escola Jurídica da Universidade de Bolonha, que promoveu sua difusão por toda Cristandade, através do estudo das compilações Justinianas, indo até mesmo para lugares onde nunca antes havia existido. A recepção desse direito pela administração de justiça ocidental foi fruto da necessidade do acolhimento de suas qualidades formais genéricas, com a crescente especialização da vida técnica.

Tal apropriação, contudo, foi notavelmente seletiva em benefício da sociedade mercantil que se formara desde o século XIV na Europa. Isso se prova no fato de vários institutos jurídicos da Modernidade serem oriundos das mesmas práticas costumeiras desenvolvidas na baixa Idade Média. Ou seja, há limites na recepção do direito romano na sociedade ocidental - que não visava, portanto, uma aplicação integral deste com o objetivo de atender às expectativas da sociedade que se formava.

Incorporando postulados formalistas do direito romano, o direito ocidental adquire seu caráter dedutivo, com seu significado universalizador e abstrato, unindo a isso o atendimento a seus requisitos formais essenciais. Altera-se de maneira profunda, portanto, a estrutura do pensamento jurídico ocidental após o resgate do direito romano.

A afirmação de Gilissen, de que "uma organização administrativa estatal desenvolve-se, suplantando a velha hierarquia feudal. (...) A lei reaparece como fonte de direito; o rei legisla tal como os príncipes territoriais e até as cidades" 6 , se encaixa no questionamento de Hespanha sobre a abrangência desse lugar comum da historiografia européia, em que a recepção do direito romano (direito comum, ius commune) teve papel fundamental na centralização do poder no princípio da Idade Moderna.

"Por um lado, porque esta recepção não foi, nem tão geral, nem tão eficaz como se pensava. E, por outro, porque a própria ordem jurídica letrada não promovia tanto como se tem dito a concentração dos poderes nas mãos do rei." 7

De acordo com o mesmo autor, "o princípio constitutivo fundamental do ordenamento jurídico moderno era o de que as normas jurídicas particulares tinham, sucessivamente, primazia sobre as normas jurídicas gerais.” 8 Ou seja, iam contra a centralização do poder. O racionalismo em favor dos particularismos faz com que, até o período da Ilustração, o direito funcione de maneira que os privilégios fossem garantidos frente ao poder central, fortalecendo a periferização dos poderes.

A problemática que buscamos desenvolver aqui gira em torno do perfil institucional do Estado português na passagem do século XV para o XVI. Mesmo neste período avançado da história do direito português, contido no que Marcello Caetano chama de Consolidação do Estado, a eficiência dos mecanismos jurídicos portugueses era muito pequena, e os problemas administrativos povoavam as principais questões de Estado.

O período em questão muitas vezes é tido como o momento em que a monarquia portuguesa assumiria um papel de Estado forte e centralizado, de onde emanariam ordens direcionadas a seus reinos e conquistas na África, Ásia e América. É significativa na historiografia contemporânea (podemos citar novamente António Manuel Hespanha como referência) que o momento em que Portugal alcançou algum tipo de sistema administrativo centralizado de bases racionais se deu somente na segunda metade do século XVIII.

\footnotetext{
${ }^{5}$ GILISSEN, John. Introdução histórica do direito. Lisboa: Ed. Calouste Gulbenkian, 2001. p. 168

${ }^{6}$ Ibid. p. 241.

${ }^{7}$ HESPANHA, A. M. História de Portugal Moderno - político e institucional. Lisboa: Universidade Aberta, 1995. p. 8990.

${ }^{8}$ Ibid. p. 90-91.
} 
Com efeito, devemos levar em consideração as diversas forças centrífugas que se opunham à vontade do rei na freqüente impossibilidade deste fiscalizar eficientemente a observância das leis nacionais. No período medieval uma das funções de maior importância atribuída à figura do rei é a de aplicação de justiça. Este representa uma das forças que, segundo Marc Bloch, "trabalhavam para limitar ou contrabalançar o desmembramento das justiças" ${ }^{9}$, e era do soberano que emanariam todo e qualquer tipo de lei ou norma jurídica a serem seguidas por seus súditos. Mediador entre Deus e povo, responsável pela manutenção da paz terrena, recebendo a comunhão no céu e velando pela manutenção da ordem através da moderação de seus súditos.

Sabendo disso, traçar este perfil institucional a partir da organização dos cargos judiciários se mostra ainda mais importante na compreensão da própria sociedade lusitana, em que, como grande parte da sociedade medieval e moderna, a vida cotidiana parecia embebida nos rituais jurídicos. Estes, numa realimentação, pareciam receber idéias difusas na sociedade e transformá-las em normas jurídicas, que acabavam por regular a mesma. Com efeito, a definição das atribuições dos cargos de justiça, de seus procedimentos-padrão (e extraordinários) contidos nas Ordenações (de D. Duarte e D. Manuel I) se configuram no nosso objeto principal de nosso questionamento.

A escolha das duas compilações se baseia no fato do momento da criação das Ordenações de $D$. Duarte (por volta de 1436) ser crucial na definição da expansão ultramarina portuguesa e das Ordenações Manuelinas (com versão definitiva em 1521) delimitarem as estruturas do império ultramarino português em pleno auge - sendo possível conhecer a maneira como o próprio Estado se definia então. Ambas são marcos da influência do direito romano sobre o direito português, e representavam a vontade do rei de que sua soberania deveria ser conhecida e cumprida como determinado. Esse momento representa diversas mudanças não só da estrutura político-jurídica do reino, mas também de sua estrutura cultural e econômica, com o impacto trazido pelos descobrimentos e expansão ultramarina, que geraram modificações significativas no perfil do Estado.

\title{
Buscando o perfil institucional de Portugal
}

\author{
De acordo com Marcello Caetano:
}

\begin{abstract}
“No espaço onde impera a autoridade política do Estado português só é verdadeiramente Direito Português o elaborado pela consciência nacional portuguesa, ou pelos órgãos legislativos competentes, tendo em vista as necessidades, as conveniências, a sensibilidade da comunidade formada pelos indivíduos que, por afinidades de cultura e civilização, se agregaram em comunidade homogênia - comunidade de crenças, hábitos, mentalidade, grau de desenvolvimento econômico, aspirações coletivas.” ${ }^{10}$
\end{abstract}

O território onde se formou e consolidou Portugal teve por habitantes uma multiplicidade de povos que contribuíram para a geração da cultura partilhada por aqueles que constituíram o país em sua independência. Isso quer dizer que a cultura portuguesa não foi algo surgido do nada, mas uma herança das que existiram antes da ascensão de Afonso Henriques. Iniciado com a independência nacional, o direito português, com efeito, se configura em uma continuação de tradições jurídicas do território em que veio a se estabelecer o reino de Portugal.

Da criação do condado portucalense nasce uma unidade política que tinha seu chefe subordinado por vassalidade ao rei de Leão e Castela, mas que depois, quando o cargo era ocupado por D. Afonso Henriques, reclama Portugal como seu direito por herança. Ele, que desde o ano de 1128 não usava mais o título de conde, e sempre considerou e exerceu os poderes de soberania como algo de que detinha a propriedade, ao intitular-se rei, quis apenas elevar-se a um estágio de igualdade com os demais príncipes cristãos peninsulares.

O rei de então era o senhor posicionado no topo da hierarquia de todos os senhores de Portugal, que se encontravam sujeitos ao monarca, uma vez estando vinculados ao território português por senhorio, propriedade ou residência. Tanto os nobres - vassalos reais - quanto o restante da população - súditos deviam fidelidade, obediência e auxílio ao mais alto senhor. As funções, e deveres, exercidos pelo monarca são a chefia militar, a justiça, a proteção à Igreja, a expansão territorial, e o enriquecimento do seu território.

Nesse período - que compreende os primeiros cem anos de Portugal - justiça e administração eram aplicadas pelas mesmas autoridades. Como diz Marc Bloch, "o prodigioso retalhamento dos poderes judiciários, e também o seu entrelaçamento” ${ }^{11}$, contribuíam para uma de suas principais características: a

\footnotetext{
${ }^{9}$ BLOCH, Marc. A Sociedade Feudal. Lisboa: Edições 70, 2001. p. 388.

${ }^{10}$ CAETANO, Marcello. História do direito português (séc.s XII-XVI). Op. Cit. p. 25-26.

${ }^{11}$ BLOCH, Marc. A Sociedade Feudal. Op. Cit. p. 374
} 
eficácia quase medíocre. Uma das grandes causas dessa confusão judiciária em que estava mergulhada a sociedade medieval, e nela incluímos Portugal, era o fato de que todos os (numerosos) chefes, ou boa parte destes, tinha o desejo de exercer o papel de juiz. Viam nessa função o efetivo controle sobre seus subordinados, afastando-os de tribunais estranhos, garantindo sua proteção e dominação simultaneamente.

A partir do reinado de D. Afonso III (na metade do século XIII), primeiro momento da Consolidação do Estado determinada por Marcello Caetano, vemos os reis tentando se firmarem como sua autoridade de verdadeiros representantes do poder político, buscando vencer e obliterar qualquer resistência interna por parte das classes privilegiadas que se colocasse em seu caminho.

Entre 1248 e 1383 podemos ver "a progressiva ação dos juristas formados no estudo do Direito Romano Justiniano, com cuja colaboração são elaboradas em número crescente leis gerais, que se impõem às tendências localistas.” 12 Trava-se um combate com os costumes da vida municipal e da autoridade senhorial, os órgãos judiciários se renovam, multiplicando-se os organismos administrativos e governamentais especializados.

Os doutores portugueses em leis, que voltam das Universidades italianas ou de Paris, trazem para o país as idéias de Estado e autoridade soberana do príncipe, retiradas do direito imperial romano, estudado a partir das compilações justinianas.

“A tendência daí por diante será cada vez mais no sentido de, embora reconhecendo ao pontífice romano a chefia da Cristandade e, por conseguinte, da sociedade internacional por ela constituída, procurar firmar a autonomia do poder temporal dos reis, reivindicando para o monarca português autoridade própria, não derivada do Papa mas resultantes dos desígnios da Providencia Divina.” 13

Tal doutrina, também desenvolvida por Afonso X de Castela, põe reis e papas em papel de igualdade em relação à origem do seu poder. Com isso, os reis só devem prestar contas de suas ações a Deus. Ele não é mais um nobre que chefia outros nobres,mas corpo e cabeça dos quais estes são membros.

A Justiça, primitivamente apoiada e regida por costumes, continua sendo a principal atribuição régia. Contudo, mesmo com o esforço da monarquia em firmar seu poder soberano a partir de uma investidura divina que lhe cedia a chefia coletiva, os reis lusitanos se viam incapazes de escapar a influência feudal. Eles tinham o reconhecimento de sua suserania traduzido na submissão pessoal de seus súditos, nas relações de dependência de pessoa a pessoa, repetida na aclamação do rei, no tradicional beija-mão e na renovação da confirmação, a cada monarca, de todas as mercês, privilégios, etc, que haviam sido feitas pelo antecessor. Não havia ainda uma noção da coroa ou realeza como uma instituição, e sim da sujeição ou submissão a um senhor (no caso, o rei).

D. Afonso III deixou mais de 200 leis, e no período em que reinou é possível perceber uma participação cada vez maior de legistas na redação destas. Também nos reinados seguintes, especialmente D. Dinis e D. Afonso IV, a promulgação de numerosas normas se mantém. Essas leis eram geralmente elaboradas por iniciativa do próprio rei, e afirmavam sua vontade ou correspondiam a sua resposta aos agravamentos ou artigos apresentados durante as cortes.

Esse primeiro momento da Consolidação do Estado é marcado também pelo grande esforço dos monarcas em organizar os sistema judiciário nacional, facilitando o recurso à justiça pública. Com o maior detalhamento de jurisdições e multiplicação de funções e de oficiais de justiça reais, vemos o início de profundas mudanças na maneira como se organiza o reino e em como o rei buscava, cada vez mais, combater e obliterar os poderes concorrentes ao seu em território português.

Contudo, a história do direito público português sofre forte influência da revolução de 1383, assim como as cortes realizadas em 1385, em que temos a ascensão da Casa de Avis na pessoa de D. João I.

“A eleição de D. João I veio quebrar a continuidade dinástica por sucessão legítima. Mas logo se retomou o costume constitucional e a coroa passou a ser transmitida por herança aos descendentes legítimos em linha reta do rei falecido, ou na falta deles, o mais próximo parente pela linha colateral legítima.” ${ }^{4}$

Neste momento o rei passa cada vez mais a personificar o reino, a encarnar o interesse geral, já que a idéia de um Estado abstrato, que detinha o poder político soberano, estava encerrada no pensamento dos legistas que seguiam o direito imperial romano contido no corpus iuris civilis. Todas as representações locais se viam subordinadas ao rei. O poder público, a lei, a união dos súditos em um país, eram o rei. O sentimento nacional nasce ligado a idéia do povo português ter um rei seu, natural de Portugal como o povo, "mesmo

\footnotetext{
${ }^{12}$ CAETANO, Marcello. História do direito português (séc.s XII-XVI). Op. Cit. p. 270

${ }^{13}$ Ibid. p. 297

${ }^{14}$ Ibid. p. 461
} 
nessa época, casamentos e sucessões não são capazes de criar qualquer Estado e nem de garantir sua duração. É preciso levar em conta o sentimento das populações.” ${ }^{15}$ O Estado do fim da Idade Média não é mais fruto da conquista e do acaso, pois adquire força por meio da coesão do povo que habita seu território.

"Não admira, assim, que se tenda a identificar o rei e a lei. Mais tarde Rousseau definirá a lei como expressão da vontade geral. Ora, quando o intérprete dessa vontade, no meio dos particularismos do xadrez social e da Idade Média, era exclusivamente o monarca, estava nele, naturalmente a fonte de direito.” ${ }^{16}$

O rei não mais somente se coloca como o legislador, como faz exceções, em casos concretos, à regra geral estabelecida por ele em lei anterior, dando solução diversa da usual de acordo com sua vontade. Sem realizar, com efeito, a observância do preceito legal. O monarca se estabelece como lei viva, sendo sua vontade uma fonte de normas jurídicas. Uma tendência maior à centralização pode ser sentida nesse momento, negando cada vez mais poderes aos municípios e às cortes.

O poder do rei era absoluto, mas não pode ser caracterizado como central. Isso se deve a diversos de fatores que condicionavam e restringiam esse poder.

"Entre eles cumpre destacar uma série de inconvenientes resultantes de uma rede vial que dificultava o acesso do monarca e do corregedor da corte a certas áreas do território, sobretudo em determinadas épocas do ano em que a circulação se tornava impraticável. (...) A manifesta carência de órgãos intermédios obriga a coroa uma cuidadosa regulamentação da vida judicial, materializando nas Ordenações do Reino as obrigações e os deveres que recaíam sobre os juizes ordinários e sobre os corregedores.” 17

E nesse momento podemos localizar a primeira tentativa de formular tais ordenações, com as Ordenações de D. Duarte, que reúnem boa parte da legislação produzida até então - em especial o que produzem D. Afonso III, D. Dinis e D. Afonso IV - em um único livro, visando, o maior cumprimento e maior racionalidade no estabelecimento das leis. Muito distinto, com efeito, do que se faz até o período do Interregno.

“Se D. Duarte, associado ao governo já nos últimos anos do longo reinado de seu pai, procurava manter o equilíbrio entre as prerrogativas da nobreza e os foros populares, o infante D. Pedro viu-se hostilizado pelo partido aristocrático, chefiado pelo herdeiro e genro de Nuno Alvarez, o conde de Barcelos, que ele fez duque de Bragança. É que D. Pedro, formado nas doutrinas medievais sobre o poder político, queria reatar a aliança com os povos que nessa altura era a condição para afirmar a idéia de Estado. E a nobreza via na regência da viúva de D. Duarte [após sua morte] o ensejo de fazer triunfar as suas pretensões de hegemonia.” ${ }^{18}$

Após um momento de novo fortalecimento dos nobres com o filho de D. Duarte (D. Afonso V), as tendências até então apontadas voltam a se mostrar com o próximo descendente.

D. João II conseguiu submeter a nobreza ao seu poder real, mesmo não extinguindo o regime senhorial, que permaneceu em sua essência. Coube a seu sucessor, D. Manuel, ampliar os feitos de seu pai, tanto nas questões da expansão dos domínios portugueses, quanto na administração do reino. Isso porque, resultaram - a parir dos descobrimentos - importantes conseqüências sociais, econômicas e jurídicas, além do esforço diplomático para consagrar Portugal internacionalmente, e do surgimento de importantes modificações na legislação interna.

"Sem dúvida, as grandes navegações e o comércio marítimo, canalizando lucros para a coroa, libertaram-na das aperturas econômicas que a obrigavam, a contragosto, a contínuas convocações das cortes, pois o rei não precisava tanto de elevar os impostos.” 19

Portanto é importante incluir o comércio marítimo entre as razões que contribuem para a configuração do perfil do Estado português, especialmente no princípio do século XVI, mesmo período em que os letrados começam a ganhar cada vez mais espaço na administração do reino, enriquecendo o

${ }^{15}$ GUENÉE, Bernard. O Ocidente nos séculos XIV e XV - Os Estados. São Paulo: Livraria Pioneira editora; EDUSP, 1981. p. 95

${ }^{16}$ CAETANO, Marcello. História do direito português (séc.s XII-XVI). Op. Cit. p. 463-464

${ }^{17}$ MORENO, Humberto Baquero. IN. TENGARRINHA, José (org.). História de Portugal. Bauru: EDUSC; São Paulo: UNESP, 2000. p. 48

${ }^{18}$ CAETANO, Marcello. História do direito português (séc.s XII-XVI). Op. Cit. p. 515

${ }^{19}$ AVELLAR, Hélio de Alcantara; TAUNAY, Alfredo D’Escragnolle. História administrativa do Brasil - preliminares européias - administração manuelina. Brasília: FUNCEP, 1984. p. 41 
romanismo centralista. As regras gerais prevalecem com as reformas trazidas com as publicações das Ordenações do reino.

Isso se torna evidente na produção e publicação das Ordenações Manuelinas, uma nova compilação legislativa, muito mais extensa que as anteriores, e que não se limitava a reunir textos previamente produzidos, mas a apresentar uma reforma no próprio texto das ordenações do reino de Portugal.

A Idade Média portuguesa apresentava a coexistência de quatro sistemas jurisdicionais: o concelhio - fundado na auto-organização das comunidades camponesas, oficializada nas cartas forais -; o senhorial que se baseia no poder disciplinar do pater sobre seu domus (domínio), todos que fossem seus dependentes -; o eclesiástico - garantindo a autonomia da jurisdição da Igreja e do Clero, além das matérias espirituais -; e o régio.

O caso do rei é interessante, pois este começou seu exercício de poder, da mesma forma que os senhores, com o direito de aplicação de justiça sobre um número limitado de pessoas. Com o passar do tempo vai-se estabelecendo, por inspiração do corpus iuirs civilis o princípio de que - já que todas as terras e homens sem senhor pertencem ao monarca - a ele pertence também a justiça, caso esta não esteja a cargo dos senhores (através de carta ou uso), ou caso estes não a estiverem exercendo devidamente.

O princípio do caráter subsidiário da jurisdição do rei português acaba, então, evoluindo para a invenção do seu caráter originário.

De acordo com Max Weber, que diz ser a dominação, caracterizada como a probabilidade de encontrarmos obediência a uma determinada ordem, fundamentada em diversos tipos de submissão,

"pode ser determinada diretamente de uma constelação de interesses, ou seja, de considerações racionais de vantagens e desvantagens (referentes a meios e fins) por parte daquele que obedece; mas também pode depender de um mero 'costume', ou seja, do hábito cego de um comportamento inveterado; ou pode, finalmente, ter o seu fundamento no puro afeto, ou seja, na mera inclinação pessoal do dominado.” 20

No pensamento weberiano existem três modelos distintos de dominação. Aqui nos interessa conhecer a dominação tradicional, que se funda na crença da existência de santidade dos atos e poderes de quem domina - estabelecendo uma relação de senhor e súdito -, dentro da qual destacamos a vertente estamental. Nesta, é flagrante a relação de fidelidade, regulada pela honra e pela patrimonialização, em que o poder se encontra repartido entre o senhor e um corpo administrativo (que goza de privilégios) por ele designado.

Marcamos a confecção das Ordenações de D. Duarte como uma primeira tentativa bem-sucedida em aperfeiçoar a administração do reino, e as Ordenações Manuelinas como um momento mais consistente neste processo, em especial, na regulamentação da vida judicial do reino. Esse primeiro tipo de dominação a analisar o poder do monarca português que, nos primórdios do reino, era exercido, de uma forma geral, da mesma maneira que o dos senhores feudais. O rei, portanto, seria mais um bellatore, uma das três ordens com responsabilidades específicas de acordo com uma organização universal de origem divina. Lembremo-nos que, até D. Afonso III, os monarcas gozavam primordialmente de uma face de chefe guerreiro.

O poder régio português, com efeito, se aproximaria da dominação tradicional de estrutura estamental formulada por Weber. Nesta, apesar do rei apresentar certa igualdade com os outros senhores, tinha seu devido destaque como líder de um povo e, por isso, era detentor do poder absoluto, estando à frente de uma estrutura administrativa. Mas, como também já observamos, isso não implica, obrigatoriamente, na centralidade do poder, uma vez que este corpo administrativo era composto por pessoas relacionadas com o monarca através de fidelidade - que era regulada pela honra - e pela cessão patrimonial de jurisdições. Falar em estadualismo, neste caso, se configura em um claro erro.

Isso quer dizer que o monarca - e aqui buscamos aproximar realmente a estrutura estamental da dominação tradicional weberiana à que encontramos no Portugal medieval - apesar de ter o reino sob seu domínio, não exercia, efetivamente, sua autoridade em todo o território em questão. Ele acaba partilhando-a com um corpo administrativo composto de um segmento privilegiado de súditos, ou mesmo se colocando de forma complacente à existência de direitos rústicos paralelos, desde que não agredissem o que estava estabelecido na normatização oficial. Segundo o próprio Weber, e como já expusemos, esta seria uma forma de dominação que se aproximaria da dominação legal, pois apresentaria uma primitiva divisão de tarefas, mesmo essa sendo feita baseada nos valores da sociedade estamental que encontramos então em Portugal.

O rei português - e de maneira geral os reis da Cristandade - pode ser considerado, não só uma estrutura política em si, mas com o passar do tempo a mais importante delas. Sua posição de senhor entre

${ }^{20}$ WEBER, Max. Metodologia das Ciências Sociais. Parte 2. São Paulo: Editora Cortez; Campinas: Editora da Universidade Estadual de Campinas, 1992. p. 349 
outros senhores, primus inter pares, começa a se modificar desde D. Afonso III (uma vez que a Reconquista dos territórios dominados pelos mulçumanos se completara ao Sul), e, acentuadamente, desde a crise dos anos 1383 a 1385. Tal transformação foi levada adiante através da multiplicação de medidas fiscais, administrativas, militares, legislativas e judiciais.

Se considerarmos o Estado como uma sociedade política com uma unidade permanente e estabilidade geográfica resistentes ao tempo, instituições aceitas pela coletividade e a existência de uma autoridade suprema à qual todos estariam subordinados, Portugal se tornava um Estado. E caberá à sua principal estrutura, o rei, incrementá-lo através dos poderes que competem à soberania: executar leis e políticas, controlar o fisco, decidir acerca da guerra e da paz, legislar, e julgar.

De acordo com o outro modelo de dominação weberiano - o da dominação legal - temos um Estado burocrático, no qual há um quadro administrativo impessoal, que segue regras racionais de comportamento com um objetivo traçado pela autoridade.

Portanto, sob o efeito, dentre outras coisas, da recepção da tradição romanística do direito na Cristandade baixo-medieval, podemos apontar uma mudança sensível na maneira como a coroa se coloca em relação àqueles que estão em seu território. Ela vai se infiltrando nos sistemas normativos sempre visando tomar para si o controle destes. Começa a se organizar de maneira que o corpo administrativo age - ou deveria, sofrendo pressões do rei para tal - menos por vontade própria e mais por vontade da ius commune (baseada na ratio), e que era controlada pelo monarca, o único legislador do reino, ainda que ele mesmo, de uma maneira geral, tivesse de se submeter à própria legislação. ${ }^{21}$

O que vislumbramos enquanto Portugal vai se aproximando da Modernidade, com a aparente necessidade de uma melhor organização interna - uma vez que aspira conquistar domínios ultramarinos -, é uma tendência a abandonar a estrutura estamental em favor de outro tipo de dominação weberiana: a legal.

Portugal já tem, na segunda década do século XVI, domínio sobre a costa ocidental da África, sobre o que viria a se tornar o Brasil, além de diversas feitorias estabelecidas na Ásia. E parecia se tornar impraticável sustentar tantos membros sem uma melhor organização na sua cabeça. E tal fato parece se constatar antes dessa multiplicidade de domínios.

Sinal disso, e da influência trazida pelas navegações, é a confecção das Ordenações de D. Duarte em um momento em que Portugal começava a se estabelecer em terras marroquinas e ilhas do Atlântico. As leis são reunidas em um livro oficial e tornadas públicas com o objetivo de amenizar a ainda fortíssima influência dos poderes particularistas na vida política do reino. O outro momento no qual nos focalizamos - o princípio do século XVI - se funda na retomada empreendida por D. João II, mas destaca a iniciativa de D. Manuel. Este dá continuidade à política conquistadora, cria as Ordenações Manuelinas, com leis mais complexas, produzidas de maneira inédita, e em volume muito maior que a de seu ancestral quatrocentista.

Não queremos, com isso, dizer que Portugal se transformou em um Estado burocratizado tal qual o modelo weberiano de dominação legal caracteriza, uma vez que este é só um instrumento sociológico que permite, através dele, uma imputação causal histórica de determinados fenômenos políticos. Mas sim que podemos identificar uma forte, e cada vez maior, tendência do monarca português na virada do século XV para o XVI em se estabelecer como a autoridade máxima de seu reino.

Havia contudo, os senhores laicos e eclesiásticos, os poderes municipais, enfim, vestígios feudais que faziam com que o processo de legalização do Estado estamental - utilizando aqui a terminologia de Weber para determinar os tipos legítimos de dominação - se colocasse apenas como uma meta. Estaríamos em um momento inicial da fase de transição do que Avellar chama de monarquia limitada pelas ordens - de caráter paternalista e popular, em que prevaleceria o direito consuetudinário -, para uma monarquia absolutista - "com um sentido tradicionalista até o século XVIII, quando começa o despotismo esclarecido pombalino." 22

Um novo perfil institucional estava sendo traçado desde o reinado de D. Afonso III, e ganhava, no período ao qual nos referimos, fortes instrumentos a favor do poder régio. A administração relativa à Justiça, uma das atribuições elementares da coroa, parece ser uma das vertentes em que mais se procurou incrementar e controlar, com o desenvolvimento de tribunais e novos ofícios.

Com o predomínio de uma visão organicista na Idade Média, a sociedade se vê hierarquizada em um modelo de rígida atribuição do papel de cada segmento, dando-se muito valor à subordinação de cada pessoa ao conjunto social. Havia os que trabalhavam, os que rezavam e os que governavam. Com o cristão sendo

\footnotetext{
${ }^{21}$ A idéia de poder absoluto, não entra em conflito com o fato de o rei estar sujeito às leis que ele mesmo impõe, uma vez que, segundo Kantorowicz, em Os dois corpos do rei, a ele está proibida a prática do mal. Sua liberdade para agir, sua condição de legibus solutus, se baseia em seu sentido inato de justiça, sua libertação das algemas do pecado.

${ }^{22}$ AVELLAR, Hélio de Alcantara; TAUNAY, Alfredo D’Escragnolle. História administrativa do Brasil - preliminares européias - administração manuelina. Op. Cit. p. 42
} 
apenas um viajante no mundo terreno, onde o pecado quebrou a ordem natural estabelecida por Deus, introduzindo a violência e a desigualdade, a necessidade de leis e de governos coercitivos se apresenta como única maneira da manutenção da paz e da ordem.

De acordo com a doutrina agostiniana desenvolvida em De Civitate Dei, a apropriação dos mecanismos judiciais por parte dos monarcas não passaria de sua obrigação - as instituições jurídicas teriam origem em um presente divino aos governantes -, e a aplicação de justiça por parte de outros, que não ele, somente existiria por esses se encontrarem na condição de delegados régios. À monarquia, então, cabe o árduo trabalho de promover a criação de um direito nacional, que funcione sob sua supervisão e controle.

Diversos mecanismos foram sendo criados à medida que se empreendia a mudança no perfil do Estado Português, objetivando sempre promover a maior centralidade judiciária (entre outras), subordinando as instituições ao rei. Destes, podemos destacar alguns cargos.

As corregedorias e ouvidorias eram magistraturas estritamente judiciárias, sendo que os primeiros parecem ter assumido papel mais importante. Por muitas vezes vê-se a tentativa de supressão do poder dos corregedores, especialmente em nome de juizes ordinários municipais, chegando a exigir-se seu extinção em 1459 em Lisboa.

Os corregedores eram magistrados judiciais à frente de correições e comarcas, e trabalhavam visitando cidades, vilas e julgados, reprimindo abusos, despachando agravos e fiscalizando a atuação de Juízes e tabeliões, além de intervir em obras públicas e na administração local. Com uma série de "auxiliares” - meirinhos, ouvidores, chanceleres, escrivães, procuradores (ou advogados), tesoureiros, porteiros, carrascos - as atribuições do corregedor tendiam sempre a expandir-se em benefício do monarca.

O rei podia, também, quando acreditava ser benéfico para o bom encaminhamento da Justiça, enviar magistrados especiais, normalmente ouvidores dos tribunais supremos, dotados de poderes plenos para atuar sem apelo ou agravo. Eram conhecidos como ouvidores de alçadas, que exerciam um temível ofício, já que, com uma assinatura, poderiam condenar, inclusive, à morte.

Havia ainda outros agentes do poder judicial, como os juízes de fora e os tabeliões. Estes, em menor grau, também contribuem para a lenta especialização da Justiça e centralização do reino, já que eram colocados no cotidiano das populações, para marcarem a presença constante da coroa em suas vidas.

Multiplicavam-se as funções e instituições responsáveis pela normatização jurídica do reino de Portugal, notadamente após a ampliação dos domínios ultramarinos portugueses. Pudemos ver isso ao analisarmos alguns ordenamentos das Ordenações de D. Duarte e nas Manuelinas, buscando identificar a evolução dessa tentativa cesarista de maior centralização régia e racionalização do aparelho estatal.

\section{As Ordenações do Reino}

As leis que conhecemos do Portugal medieval só nos vêm à tona a partir de compilações tardomedievais. As principais fontes utilizadas pela historiografia que visam reconstituir a legislação medieval são o produto da atividade de juízes ligados à corte - Livro das Leis e Posturas, Ordenações -, ou à administração local - Foros da Guarda.

“No fundo, um critério semelhante ao de posteriores fontes do mesmo tipo ('livros de assentos', 'livrinhos ou livros de leis'). Em uns e outros não faltam textos de natureza claramente doutrinal ou jurisprudencial (e não 'legislativo').", 23

De acordo com o que afirma Hespanha, podemos situar 250 leis desde o surgimento do reino português até o século XIII, 220 entre 1248 - ascensão de D. Afonso III - e 1279, e apenas 150 no que corresponderia aos séculos XIV e XV. Tal estatística, contudo, não é muito precisa uma vez que muitos desses textos legislativos não estão datados.

Desse conjunto legislativo podemos destacar as determinações régias no curso do seu poder “imperial” - referentes à repressão ao crime, visando a manutenção da paz através de leis penais e erradicação da vindicta -, disposições do rei sobre os reguengos e ofícios reais, disposições da corte e normas de decisão do tribunal da corte - em muitos casos preceitos doutrinais ou costumeiros, mas normalmente uma decisão real.

No que diz respeito às Ordenações do reino, que se inserem nessa produção, sabe-se que cobriam a normatização administrativa tanto local quanto central, sendo seu principal domínio a regulamentação da justiça da maneira como era então definida: mais voltada para o âmbito administrativo, e não para o domínio fiscal-financeiro.

${ }^{23}$ HESPANHA, A. M. Panorama da cultura jurídica Européia. Op. Cit. p. 112 
O que faremos a seguir é analisar as Ordenações de D. Duarte, confeccionadas no século XV e as Manuelinas, do século XVI, procurando uma evolução na organização e na redação das leis que se referem à administração judiciária - de grande importância na constituição do perfil institucional do Estado Português, como já apontamos anteriormente - contidas em ambas compilações, a fim de confirmarmos a tendência a uma primitiva burocratização do Estado estamental.

“As Ordenações de D. Duarte, constituem, sem favor, como sabem todos os que se dedicam à história do direito e à Idade Média em Portugal, um dos mais importantes monumentos legislativos nacionais e, porque a ordem normativa é reflexo da vida e simultaneamente procura discipliná-la em todos os aspectos, instrumento necessário de trabalho para quantos intentam reconstituir o (...) período medievo.” ${ }^{24}$

De uma maneira geral, as Ordenações obedecem a um critério cronológico em sua sistematização. São constituídas de leis escritas desde D. Afonso II até o próprio D. Duarte. Interessante notar que o maior volume de leis se concentra em três reinados - de D. Afonso III, D. Dinis e D. Afonso IV -, e que a produção relativa aos reis da dinastia de Avis é reduzido em comparação à maioria de seus antecessores (em especial aos três citados). D. Duarte aparece com menos ordenações do que seu pai, D. João, provavelmente um reflexo da curta duração de seu reinado (o que não atrapalhou sua participação desde cedo nos assuntos de Estado, como já observamos em um capítulo anterior). A maior parte da normatização que analisaremos se concentra, então, no período de reinado de D. Afonso IV, último dos três monarcas de mais larga legislação voltada para justiça. A escolha se definiu pelo fato de - por ser o dito monarca o mais próximo cronologicamente de D. Duarte - as leis de Afonso IV seriam as mais fiéis ao que era aplicado em seu reino. Nesse primeiro recorte, portanto, nos encontraremos na passagem de quase um século após o início do primeiro momento do que Caetano definiu como Consolidação do Estado. Destacaremos antes, contudo, duas ordenações referentes à D. Dinis.

A maioria das leis contidas nas Ordenações haviam sido redigidas, com efeito, muito tempo antes do reinado de D. Duarte. Em razão disso, o critério usado pelos copistas dos manuscritos originais parece ter sido o de se manter fiel aos conteúdos e de uma "liberdade adaptadora (aos usos da época e do copista) quanto à forma. Por 'forma' entenda-se a grafia, a ortografia e, em parte, a gramática; que eram, naturalmente, 'modernizadas'”, 25

Um bom exemplo para chegar onde desejamos é a ordenação redigida por D. Dinis em 1 de Julho de 1320. Nesta, vemos representada a afirmação do rei como autoridade máxima nos assuntos relacionados à justiça. Na lei que determina que ninguém apele para outra pessoa que não o rei, D. Dinis se dirige a todos os "meestres Priores abades comendadores E aluazijs E Juizes E alcajdes E Justiças E conçelhos E a toda-los outros que ouuerem a Julgar preitos” ${ }^{26}$ em Portugal. Ou seja, a todos os que, de alguma maneira estão envolvidos com a aplicação de justiça no reino. Após constatar que muitos estavam julgando sem sua permissão, consultando seu irmão - futuro Afonso IV -, seu conselho e sobrejuízes, decide que "todo-los de meus rregnos que apelarem dos Juizes ou aluazijs ou d'alcaides ou de Justiças ou doutros que os Julgarem que apelem primeiro pera mym E pera minha Corte E nom apelem pera outro nenhuum ${ }^{27}$." ${ }^{28}$ Afirma-se assim, que o poder de julgar emana única e exclusivamente do rei, que, como a cabeça do corpo político, "era comparado com Cristo, a cabeça do corpo místico da Igreja.” ${ }^{29}$ A função justiça é centralizada, o que podemos confirmar em sua última afirmação, de que "nem-huum nom seja ousado de sse chamar ssobreJuiz nem meirjnho nem usar ende do oficio se nom for meu E per meu mandado.” 30

Como exemplo da preocupação régia em dinamizar os processos jurídicos podemos encontrar a ordenação intitulada "Como hi nom aJa mais de tres audiancias." ${ }^{31}$ Nesta, o rei determina o número máximo de audiências que cada caso, visando “tolher E escusar esta delonga.” ${ }^{32}$ na determinação da sentença dos

\footnotetext{
24 ALBUQUERQUE, Martim de; NUNES, Eduardo Borges. Ordenações Del-Rei Dom Duarte. Lisboa: Fundação Calouste Gulbenkian, 1988. p. V

${ }^{25}$ Ibid. p. XXXI

${ }^{26}$ Ibid. p. 165

${ }^{27}$ Fazemos aqui uma importante observação no que concerne à transcrição do texto original de ambas Ordenações do reino com que trabalhamos: Na impossibilidade de acentuamos com o acento gráfico "jota" ( ) as letras "U” e "E”, em razão de tal função se mostrar indisponível no redator de texto que utilizamos, substituiremos tais acentuações por "un”; "um”; “en”; “em”. Todos sublinhados desta maneira, indicando a modificação do texto original.

${ }^{28}$ Ibid. p. $165-166$

${ }^{29}$ KANTOROWICZ, Ernst H. Os dois corpos do rei - um estudo sobre teologia política medieval. São Paulo: Companhia das Letras, 1998. p. 138

${ }^{30}$ ALBUQUERQUE, Martim de; NUNES, Eduardo Borges. Ordenações Del-Rei Dom Duarte. Op.Cit. p. 166

${ }^{31}$ Ibid. p. 312

${ }^{32}$ Ibid.
} 
julgamentos. Em primeira instância o julgamento é feito por um sobrejuiz, auxiliado por três ouvidores. Caso queira fazer-se apelação, será feita para esses ouvidores, que poderão revogar ou confirmar a sentença do sobrejuiz. Não está muito clara a maneira como se daria a terceira audiência, mas nos parece que esta é feita em apelação direta ao rei: "sse as partes ouuerem sospeito o sobreJuiz ou alguum dos ouujdores uenham a nos quando na cassa formos." " 33 Neste caso o procedimento se constitui na troca do sobreJuiz e manutenção dos advogados, procuradores e escrivães.

É importante notar a preocupação em detalhar cada procedimento, o número de oficiais envolvidos, e suas funções especificas em cada etapa do procedimento, para que uma das principais atribuições régias fosse executada de uma forma tão infalível quanto este escolhido de Deus faria em pessoa. Tal tendência aponta para a organização da justiça como uma instância privilegiada na administração do Estado português.

As Ordenações de D. Duarte, com efeito, se mostram realmente como uma grande compilação de leis publicadas com o passar dos séculos, parecendo ser sua mais efetiva observância de grande interesse a este monarca no processo de reafirmação de seu poder, ainda que estas não constituíssem o único conjunto de leis publicado. Mas é importante observar que esse esforço se resume menos a uma reforma legislativa do que à tentativa de que antigas leis fossem observadas. É verdade que o próprio D. Duarte produzira algumas leis, mas em número reduzido se comparadas à produção dos três monarcas citados anteriormente. Sua preocupação parece realmente demonstrar a força que a palavra dos reis têm, ao adotar e reforçar aquilo que determinaram.

Suas intenções de centralização, mesmo que pouco efetivas em diversas ocasiões, demonstram vontade em fazer do rei muito mais do que um senhor entre senhores. E sim constituí-lo em autoridade máxima, de onde emanam as leis e que espera que estas sejam cumpridas em benefício de sua função de mantenedor da ordem e da paz.

Já no século posterior, temos um exemplo mais bem acabado de compilação. De acordo com Marcello Caetano,

“foram os autores da primeira versão das O.M.: o chanceler-mor Rui Boto, o licenciado Rui da Grã e o bacharel João Cotrim, os quais em fevereiro de 1506 já estavam a trabalhar na obra que o rei queria rapidamente feita e acabada. Em 17 de dezembro de 1512 o impressor Valentim Fernandes lança o livro I das novas Ordenações, seguido do II, em 18 de Novembro de 1513.” 34

A primeira edição, de 1512 e 1513, a cargo de Valentim Fernandes publicou apenas os livros I e II. No mesmo ano de 1513 foi contratado João Pedro Bonhomini para produzir uma segunda edição, sem as falhas que aparentemente apresentou a primeira, começando a ser publicada efetivamente em março de 1514.

No prólogo da edição de 1514 encontra-se uma justificativa de D. Manuel para tal reforma. Segundo ele, as Ordenações de seus antecessores causavam muitas dúvidas e confusões, o que acabava por gerar muitas perdas a partes envolvidas em processos diversos. A nova compilação, portanto, teria como objetivo retirar tudo que fosse supérfluo, todos os defeitos, contradições, etc. para que fosse mais simples de se entender e que, assim, a lei fosse cumprida de uma forma mais correta. Mesmo assim, o resultado não lhe pareceu satisfatório, no que a última versão - a que acabamos por usar em nossa análise - acaba sendo publicada no ano de sua morte: 1521 . Todas as outras versões deveriam, de acordo com carta régia de 15 de março de 1521, ser destruídas sob pena de multa e degredo.

Na introdução que podemos encontrar na edição que utilizamos, temos uma observação interessante acerca dos motivos que teriam levado D. Manuel à confecção das Ordenações.

"Ao monarca venturoso, que em seu tempo assistiu a pontos altos da gesta dos descobrimentos, não seria indiferente ligar o nome a uma codificação de vulto. Trata-se de conjectura alicerçada em vários testemunhos, inclusive numa confessada importância atribuída pelo rei ao direito e à realização da justiça. As preocupações legislativas de D. Manuel I foram patentes, traduzindo-se também na importante reforma dos forais, que se concretizou em 1520, após tentativas frustradas de seus antecessores.” 35

A nova edição, impressa pelo alemão Jacob Cromberger, se organiza em cinco livros, divididos em títulos e parágrafos. Contudo, podemos observar que, em qualquer das versões, é relevante a mudança de estilo das compilações, pois se encerra a preocupação histórica de se compilar as leis dos monarcas sucessivos nos mesmos termos em que foram originalmente redigidas. Mesmo quando aproveitadas e/ou

\footnotetext{
${ }^{33}$ Ibid. p. 313

${ }^{34}$ CAETANO, Marcello. História do direito português (séc.s XII-XVI). Op. Cit. p. 620

${ }^{35}$ COSTA, Mário Júlio de Almeida. Ordenações Manuelinas - volume 1. Lisboa: Fundação Calouste Gulbenkian, 1984. p. 6
} 
mantidas, os conteúdos são expostos em estilo legislatório, ou seja, como se emanasse diretamente de D. Manuel.

Havia ainda uma profunda preocupação que fossem observadas as normas da versão definitiva das Ordenações Manuelinas de maneira fiel, desconsiderando-se qualquer versão anterior. Aos juízes que não cumprissem tais determinações podia ser imposta a suspensão do ofício, além de multa.

“Não tinham os juízes, sequer, liberdade de interpretação: se no despacho de um feito todos os desembargadores ou alguns deles tivessem alguma dúvida sobre o entendimento de certa ordenação, deveriam expô-la ao Regedor para que a apresentasse em Mesa Grande (sessão plenária) que resolveria por sentença. E se na Mesa Grande perdurasse a dúvida, o Regedor apresentá-la-ia ao Soberano para que a resolvesse. A interpretação sem seguir esse processo implicava a suspensão do juiz.” 36

No primeiro livro, no qual realizamos a análise exposta a seguir, podemos encontrar os regimentos referentes aos magistrados e oficiais dos tribunais da corte, corregedores das comarcas, ouvidores locais, juízes (ordinários e de fora) e diversos outros ofícios relacionados à aplicação da justiça. "A expansão ultramarina portuguesa deixa aqui e ali os seus sinais. São [por exemplo], no livro I, os Desembargadores das Ilhas (tít. 8)." 37 Assim como fizemos com as Ordenações de D. Duarte, destacaremos uma pequena fração dessas Ordenações a fim de atingirmos os objetivos propostos neste trabalho, nos concentrando no procedimento da aplicação de justiça no reino e na especificação das atribuições dos funcionários importantes em sua execução.

No prólogo das ordenações, nos diz D. Manuel que a justiça, em tempos de paz ou de guerra, “pera boa gouernança, e conseruaçam de toda Repubrica, e Estado Real, a qual como membro principal, e sobre todas as outras virtudes excellente, mais que todas aos Principes conuem.” ${ }^{38}$ Continua dizendo que o bom rei deve sempre tratar todos com o mesmo critério de justiça, dando a cada um o que merecem.

“e fazendo-os bem viuer, os bons com prêmios, os máos com temor da pena, donde resulta paz, e asesseguro, porque o castigo dos máos he conseruaçam dos bons, assi deue fazer o bom Príncipe, pois que per Deos foi dado principalmente nom pera si, nem seu particular proueito, mas pera bem gouernar seu pouo, e aproueitar a seus subditos, como a proprios filhos." 39

Continua dizendo que o bom Estado se funda em armas e leis, pois fora assim que os romanos subjugaram boa parte do mundo. E nas armas e contínua guerra travada na África e Ásia "sejamos occupados, desejando Nós conseruar, e manter Nossos Vassallos em perpetua paz, e bons costumes.” 40

Termina afirmando o que já observamos anteriormente, de que, consultando seus letrados e conselheiros, viu a necessidade de reformar as Ordenações do reino a fim de obliterar erros, contradições e tudo mais que pudesse impedir a manutenção da perpétua paz. Feito o trabalho, exprime a vontade de que "em todos os Nossos Reynos, e Senhorios se guardem, e pratiquem, e valham para sempre” "41, não esquecendo do cancelamento de quaisquer outras ordenações publicadas anteriormente, com exceção das escritas no Livrinho Rolaçam.

O primeiro título do primeiro livro das Ordenações, - intitulado "Do Regimento do Regedor da Justiça na Casa da Sopricaçam" ${ }^{42}$ - começa tratando do "maior e mais principal Officio da Justiça de Nossos Reynos, e senhorios.” ${ }^{43}$ As características necessárias ao detentor de tão nobre ofício são este ser fidalgo de limpo sangue, ser bom, virtuoso, capaz de exercer sua autoridade de maneira competente e justa, ser letrado e temente a Deus. Não pode ser capaz de nenhuma perversão ou paixão que vão interferir na boa condução de justiça a todos os que têm esse direito. É necessário de que seja bem abastado de bens temporais - de riquezas - para que sua necessidade pessoal não cause alguma "corrupçam de Nossa Justiça." ${ }^{44}$ Fica claro que o rei reconhece que muitos oficiais, em razão da ganância (supostamente fruto da necessidade), se beneficiavam da posição de que gozavam para, através de atos de corrupção que deturpariam a boa justiça, reunir riquezas particulares. Exigir uma série de qualidades, inclusive a posse de suficientes bens temporais, lhe parece a medida a ser tomada para evitar tais desvios.

\footnotetext{
${ }^{36}$ CAETANO, Marcello. História do direito português (séc.s XII-XVI). Op. Cit. p. 626

${ }^{37}$ Ibid.

${ }^{38}$ COSTA, Mário Júlio de Almeida. Ordenações Manuelinas. Op. Cit. p. I

${ }^{39}$ Ibid. p. I-II

${ }^{40}$ Ibid. p. II

${ }^{41}$ Ibid. p. III

${ }^{42}$ Ibid. p. 01

${ }^{43}$ Ibid.

${ }^{44}$ Ibid. p. 02
} 
Há ainda a necessidade deste alto oficial ser natural - ou seja, português - para que sirva de maneira mais fiel ao monarca, ao Estado e aos serviços exigidos pelo cargo.

Em seguida, vemos novamente a afirmação do papel central que tem a justiça nas funções régias, no ponto em que se justifica a necessidade de tantas recomendações com relação a este importante cargo da administração judiciária. O rei diz que a justiça é a principal causa "porque com a graça de Deos por ella Reynamos, e a ella sobre todalas cousas deste mundo Tenhamos por isso maior obrigaçam, pera com equidade sempre a Guardamos a todos, assi a razam, e ella mesma Justiça Nos aconselha.” 45 Notemos aqui a razão - ratio - aparecendo como parte essencial da justiça.

No Regimento, portanto, o monarca explica a importância do cargo do regedor, pois transmite uma série de responsabilidades, fundamentalmente do poder régio, a esse oficial, que deve proceder com o máximo de responsabilidade. Transmite-se tal poder baseando-se na confiança do que sede à boa condução daquele que recebe. Para isso, cada regedor que fosse assumir seu ofício deveria fazer um juramento solene em cerimônia pública, conduzida pelo chanceler mor, na presença do rei e dos desembargadores da Casa de Relação. Cerimônia parecida a que são submetidos todos os desembargadores da Casa de Suplicação, corregedores das comarcas, ouvidores e juízes de fora quando providos de seus ofícios.

O Regimento do regedor da Casa de Suplicação é bem extenso, diz ao regedor que organize os desembargadores da Casa de Suplicação nas mesas dos ofícios ordenados da maneira que lhe parecer mais adequada, "segundo a qualidade e quantidade dos feitos. Dando porem nos feitos crimes, em que alguma pessoa seja acusado por caso, que provado meresse morte, ao menos quatro desembarguadores” 46, que somados ao Juiz do feito formando um grupo de cinco oficiais, sendo somente dada a sentença de morte, ou absolvição, em caso de concórdia da maioria.

Nos demais casos criminais, contudo, serão somados ao Juiz do feito somente dois desembargadores, formando um grupo de três. Há a indicação de que seria necessária a concórdia de dois destes para se efetivar a sentença, nem que, em caso de cada um decidir por uma sentença diferente, vão-se somando desembargadores até que uma das sentenças seja acordada por dois.

Ressaltemos a permanência da ordem do rei de que todos os feios sejam realizados com o máximo de urgência possível, evitando-se as delongas já presentes nas centúrias anteriores, e aparentemente persistentes no século XVI. Talvez por buscar tal dinamização possamos encontrar descrições minuciosas - e até práticas - da maneira como se deve em caso de dúvida na sentença, especialmente quando esta envolve a pena de morte.

"Tera isso mesmo grande resguado, que o tempo se nom guaste em falas, e praticas nom necessarias, nem em outras semelhantes ocupações em que se guaste o tempo como nom deue.” 47

Busca-se dinamizar, então, o desembargo - de duração máxima de quatro horas -, que, enquanto durar, "o Regedor nom consentirá que os Fidalguos, nem outras pessoas venham aa Rolaçam, saluo quando forem chamados; e se d’outra maneira lá quiserem entrar, e seja-lhe dito que nom podem por entam lá hir.” 48 Caso quisessem, poderiam mandar algo por escrito, mas não entrar. Sinal claro da tentativa de se esquivar de uma sala superlotada e de um desembargo decorado com mais discursos de retórica do que já lhe é habitual.

No que se refere à justiça que cobre todo o reino português, temos, no título vinte e nove, o "Regimento do Guouernador da Justiça na Casa do Ciuel” ${ }^{49}$, ofício que tem como objetivo entender e prover

"sobre as contendas, e litigios, que sam acerca dos bens, e fazenda dos Nossos Vassalos, e naturaes, e assi sobre o Regimento da Justiça da Nossa Cidade de Lixboa, que he a maior, e mais nobre de Nossos Reynos, e Senhorios, em que muito consiste Nosso seruiço, e vniversal Justiça dos ditos Nossos Reynos, e por tanto teer a gouuernança da dita Casa he nella Officio maior e mais principal, e assi acerca de Nós, e de Nosso Estado de tanto peso, e estima, que por Nós, e Nossos Socessores se deue procurar, que o Guouernador della seja sempre com aprouadas e mui vertuosas qualidades de sua pessoa pera este Officio escolhido.” 50

Temos aqui uma contradição. No regimento do regedor da Casa de Suplicação diz-se que este goza do maior e mais importante ofício de Justiça dos reinos e senhorios do monarca português, o mesmo que se expressa a respeito do governador da justiça da Casa do Cível. Assumamos, portanto, que ambas posições

\footnotetext{
${ }^{45}$ Ibid.

${ }^{46}$ Ibid. p. 11

${ }^{47}$ Ibid. p. $11-12$

${ }^{48}$ Ibid. p. 13

${ }^{49}$ Ibid. p. 183

${ }^{50}$ Ibid.
} 
gozam de prestígio e importância equivalentes, já que, como veremos, guardam qualidades e obrigações em comum.

Isso se confirma na seqüência do texto do regimento do governador da justiça, onde o rei destaca as qualidades que este deve possuir - ser fidalgo, virtuoso, bom, justo, de limpo sangue, temente a Deus, sem paixões e ter autoridade - para aplicar a justiça de forma correta, rápida e igual a todos os que procurarem seus serviços. Mais um ponto em comum com o regedor da Casa de Suplicação é a recomendação régia que o governador seja homem de bens temporais, já que a posse de riquezas configuraria impedimento à necessidade de corrupção de sua parte. Como dissemos antes, esse fato indica que a corrupção dos altos oficiais era algo relativamente comum, mas que, ao menos de acordo com o texto, isso se fazia mais por necessidade do que por ganância, o que é difícil de acreditar.

Exige-se, ainda, que o governador seja natural - português - e que deseje servir ao rei, amando "perfeitamente Nossa Pessoa, Estado, e Seruiço; porque assi como a Justiça he causa mais principal, porque com Graça de Deos por ella reinamos, e a ella sobre todalas cousas deste mundo Tenhamos por isso maior obrigaçam." 51

Novamente temos o reforço da dedicação do oficial, e o reforço da doutrina agostiniana na qual o rei governaria em razão, fundamentalmente, da doação divina que lhe deu o direito - e dever - de aplicar a justiça na terra a fim de promover a manutenção da paz e da ordem. Fração desta função régia, portanto, se encontra em poder do governador, e, por isso, deve seguir todas as recomendações e corresponder a todas a exigências daquele que a cedeu.

Mesmo com toda essa evolução que pode ser constatada nas Ordenações Manuelinas, parece ser difícil afirmar que houve modificações radicais e profundas no direito português. Como dissemos, a maioria destas novas leis eram as antigas redigidas de um modo legislatório, visando, inclusive, supervalorizar a força e influência do monarca. Porém, a principal diferença e evolução que podemos destacar nesta compilação quinhentista é o esforço para que fosse mais simples de se entender que as predecessoras, e que, desse modo, a lei fosse cumprida de uma forma mais eficiente. O desenvolvimento do direito português tinha abertas para nos colocarmos de uma maneira mais correta - novas perspectivas.

No que concerne à administração judiciária, portanto, destacamos aquilo que confirma de certa maneira a tendência por nós já apontada: a de que o rei buscava delimitar a ação de seus oficiais através da repetição do discurso que dizia de onde emanava todo e qualquer poder de julgar dentro dos limites do reino português (de seu rei, evidentemente), da especificação de suas funções, de que maneira deveriam se portar em cada caso, e as punições que sofreriam caso fossem contra tais determinações. O perfil institucional do Estado português se definia na tentativa cesarista de que a autoridade do rei vinha baseando-se cada vez mais em um projeto de organizar o Estado por preceitos mais racionais, ainda que, como já afirmamos, a idéia de estadualismo esteja muito distante do que podemos encontrar na prática no Portugal desse período, sendo necessários mais de trezentos anos para que tal projeto seja efetivamente concluído.

\section{Considerações finais}

O Estado português, e, na verdade, o rei de Portugal como uma instituição, com a recepção do direito romano, a maior estabilidade política frente à ameaça castelhana, e suas pretensões de conquista e manutenção de um império que cobria três continentes além do seu próprio, vivia uma significativa tendência à mudança da dominação do tipo tradicional - configurada em um Estado do tipo Estamental - segundo o modelo weberiano, que podíamos encontrar neste reino originalmente feudal.

Os descobrimentos trouxeram uma ampliação na noção européia do que era o mundo, e uma série de condições e exigências ao governo lusitano; o direito romano fornece as bases legais para uma mudança nos valores institucionais, fazendo com que no período tardo-medieval possamos ver mudanças significativas nas perspectivas acerca da maneira como se encarava a estrutura do reino português - agora uno e responsável por terras além mar - e de como se buscaria reforçar a autoridade régia à frente do império ultramarino que se formava. Comparar a organização das Ordenações de D. Duarte e as Manuelinas nos deu uma idéia de como o governo lusitano buscava suprir a carência de órgãos intermédios, a fim de atenuar o débil centralismo que podemos apontar em uma monarquia do tipo feudal.

As bases jurídicas que sustentavam a legitimidade da dominação exercida pelo monarca português sofriam modificações. Portugal, em seus primeiros séculos como reino independente, se baseava nos preceitos medievais do rei como um chefe guerreiro em meio à instabilidade militar em que se encontrava a Península Ibérica. Um senhor entre senhores - já que tal instabilidade exigia a existência de poderes particularistas

\footnotetext{
${ }^{51}$ Ibid. p. 184
} 
capazes de manter a integridade do território - que fundava sua autoridade na detenção do poder de aplicar justiça e de ter sob laços feudais a fidelidade dos poderosos de seu reino.

Ao mesmo tempo em que se aproximam os grandes descobrimentos ultramarinos, começam a ser criados, lentamente, mecanismos de organização do Estado, com o objetivo de combater a pluralidade de poderes que acabam de agir de forma concorrente ao poder régio na normatização social - o concelhio, o senhorial e o eclesiástico.

A recepção do direito romano imperial (contido no código Justiniano), resgatado a partir de estudos desenvolvidos inicialmente nas universidades italianas, e depois na Europa - chegando em Portugal, inicialmente, através de uma elite eclesiástica culta, que estudava nas universidades do sul da Europa ou se integrava a círculos monásticos fora do reino português - contribui para essa busca do poder régio em combater a pluralidade medieval. Vimos, contudo, que é possível questionar o papel da recepção do direito romano - na opinião de Hespanha, superestimado pela historiografia européia. A complacência com direitos rústicos paralelos, contudo, não impedia os monarcas de buscarem o direcionamento do direito oficial no caminho da centralização.

A postura da coroa portuguesa em relação aos seus súditos vai se modificando, então, à medida que seu poder vai se estendendo a senhorios ultramarinos. A jurisdição do rei, que sofria forte concorrência de outras esferas de poder, assume um caráter subsidiário, força sua infiltração nos sistemas normativos, e vai, pouco a pouco, inventando um caráter originário. As navegações e o comércio marítimo dão respaldo a essa busca por uma maior autoridade por parte do rei, uma vez que sustentam economicamente um reino que - por essa razão - precisa recorrer menos à convocação das cortes.

O principal ponto reforçado, e por nós analisado, nas Ordenações era o poder fundamental do monarca de aplicação da Justiça - de acordo com as doutrinas de Santo Agostinho e dos textos romanizantes de Afonso X -, que se configura na principal atribuição do poder temporal.

Na Idade Moderna - pelo menos até o século XVIII - não se podem ver grandes rupturas em Portugal. Apesar dos esforços régios (através do envio de magistrados nomeados pelo monarca), os concelhos permanecem relativamente autônomos. Em menor escala, alguns senhores conservam seus direitos de aplicação de justiça - fato que pudemos ver na confirmação, acompanhada, contudo, de fiscalização, de privilégios concedidos pelo rei e gozados por esse segmento da sociedade lusitana quinhentista. A fidalguia ainda teria vida longa e se estenderia às colônias do vasto império português. A justiça eclesiástica continuou fundada na jurisdição dos bispos.

O que apontamos como esse novo perfil institucional do Estado português, na verdade, se configura na multiplicação de mecanismos através de iniciativa régia - e a especificação e revisão das atribuições e funcionamento dos ofícios e instituições ligadas à aplicação de justiça no reino representam a faceta desses mecanismos que analisamos nas Ordenações -, que têm como objetivo principal promover a centralidade do monarca lusitano no controle de seu reino. A principal realização que podemos indicar, portanto, é a abertura de novas perspectivas para o desenvolvimento do direito em Portugal.

O objetivo dessa multiplicação de mecanismos é o que fica em suspenso. E nele se localiza a maior dúvida, uma vez que nos parece improvável - quiçá impossível - imaginar um projeto racionalizador por parte do governo monárquico português, e é aí que essa nossa discussão fica em aberto, para futuras reflexões a respeito da modernidade do Portugal dos séculos XV e XVI.

\section{Referências bibliográficas}

ALBUQUERQUE, Martim de; NUNES, Eduardo Borges. Ordenações Del-Rei Dom Duarte. Lisboa: Fundação Calouste Gulbenkian, 1988.

AVELLAR, Hélio de Alcantara; TAUNAY, Alfredo D’Escragnolle. História administrativa do Brasil - preliminares européias - administração manuelina. Brasília: FUNCEP, 1984.

BLOCH, Marc. A Sociedade Feudal. Lisboa: Edições 70, 2001.

BOXER, Charles R. O Império Marítimo Português: 1415-1825. São Paulo - SP: Companhia das Letras, 2002.

CAETANO, Marcello. História do direito português (séc.s XII-XVI). seguida de Subsídios para a história das fontes do direito em Portugal no séc. XVI. Editorial Verbo: Lisboa, 2000.

COSTA, Mário Júlio de Almeida. Ordenações Manuelinas - volume 1. Lisboa: Fundação Calouste Gulbenkian, 1984 
GILISSEN, John. Introdução histórica do direito. Lisboa: Ed. Calouste Gulbenkian, 2001.

GUENÉE, Bernard. O Ocidente nos séculos XIV e XV - Os Estados. São Paulo: Livraria Pioneira editora; EDUSP, 1981.

HESPANHA, A. M. História de Portugal Moderno - político e institucional. Lisboa: Universidade Aberta, 1995.

KANTOROWICZ, Ernst H. Os dois corpos do rei - um estudo sobre teologia política medieval. São Paulo: Companhia das Letras, 1998.

MORENO, Humberto Baquero. IN. TENGARRINHA, José (org.). História de Portugal. Bauru: EDUSC; São Paulo: UNESP, 2000.

WEBER, Max. Metodologia das Ciências Sociais. Parte 2. São Paulo: Editora Cortez; Campinas: Editora da Universidade Estadual de Campinas, 1992. 